\title{
Mass Balance Modeling for Planning Contaminant Loading and Remediation Techniques on a Watershed Scale
}

\author{
Kealy A. Dedman, Raymond T. Guther, John Choo and Ronald B. \\ Scheckenberger
}

Many agencies and stakeholders in the Regional Municipality of HamiltonWentworth have long recognized the need for watershed planning, particularly for the Red Hill Creek watershed, located in the City of Hamilton's east end. Watershed planning allows for comprehensive and holistic assessment of resources, impacts and mitigation. In 1996, the Region initiated Phase One Data Collection activities to support the preparation of a watershed plan, formally initiated in 1997 to be completed by mid-1998.

The watershed plan focused on a series of action plans addressing issues and concerns raised by stakeholders and agencies. A multi-disciplinary team of experts and stakeholders addressed a comprehensive list of areas including fisheries, terrestrial resources, surface and groundwater characteristics and quality, stream morphology, cultural heritage, air quality, and contaminant sources.

Methods were developed to define the current state of the watershed, as well as to evaluate the changes arising from future activity. This chapter focuses on how in-stream water quality was assessed under the various land use and management conditions considered.

Dedman, K.A., R.T. Guther, J. Choo and R.B. Scheckenberger. 1999. "Mass Balance Modeling for Planning Contaminant Loading and Remediation Techniques on a Watershed Scale." Journal of Water Management Modeling R204-03. doi: 10.14796/JWMM.R204-03.

(C) CHI 1999 www.chijournal.org ISSN: 2292-6062 (Formerly in New Applications in Modeling Urban Water Systems. ISBN: 0-9697422-9-0) 


\subsection{Introduction}

\subsubsection{Watershed Description}

The Red Hill Creek watershed drains $64 \mathrm{~km}^{2}$ to Hamilton Harbour and consists of seven subwatersheds, each with unique land use and drainage system characteristics (Figure 3.1). The upper (headwater) subwatersheds, which comprise $70 \%$ of the total watershed area, include Greenhill, Upper Ottawa, Hannon and Upper Davis Creek watersheds. The lower (Red Hill Valley) subwatersheds, located below the Niagara Escarpment, include Red Hill Valley, Lower Davis and Montgomery Creek watersheds.

There are few natural storage sites for stormwater (wetlands, pools and other depressions) within the Red Hill Creek Watershed. More than half of the watershed has an urban drainage system; approximately $50 \%$ of the urban area is drained by combined sewer systems. The storm sewer systems discharge to the Red Hill Creek at various locations while the combined sewer system normally discharges to the Woodward Avenue Sewage Treatment Plant. During significant rainfall events when the sewage treatment plant or local sewer capacity is exceeded, however, the combined sewer systems also discharge to the Red Hill Creek at four primary locations (Greenhill, Lawrence, Queenston and Melvin, Figure 3.1).

Overall, the instream water quality of the Red Hill Creek is influenced by a number of factors. The natural geological conditions of the watershed affect background concentrations of various constituents, principally metals. Since the watershed is highly urbanized, removal of vegetation and runoff from paved surfaces has influenced a number of constituents, including polycyclic aromatic hydrocarbons (PAHs) and metals. The servicing standards of the urban region, which have historically included combined sewer overflows (CSOs), have contributed organic enrichment to the creek. Finally, agricultural land use practices in the upper watershed may have influenced contaminant levels in the waterway.

Generally, water quality in the Red Hill Creek is reasonably good during low flow (non-storm) conditions (Wenghofer et al, 1997). Most constituents are within provincial water quality objectives (PWQO), with the exception of some metals, nutrients and bacteria. Bacterial contamination has been identified as the primary impairment under low flow conditions, although the source is unknown. Dissolved oxygen levels do not generally appear to be a limiting factor for aquatic life, however further sampling at critical periods may be required to confirm this.

The principal water quality concerns for the Red Hill Creek involve water quality deterioration during rainfall/runoff events. During these events, primary water quality pollutants include: metals, $\mathrm{PAHs}$, suspended sediment, and bacteria. As well, certain areas of the watershed have been identified as contributing to elevated nutrient levels (e.g. phosphorus, nitrogen). 


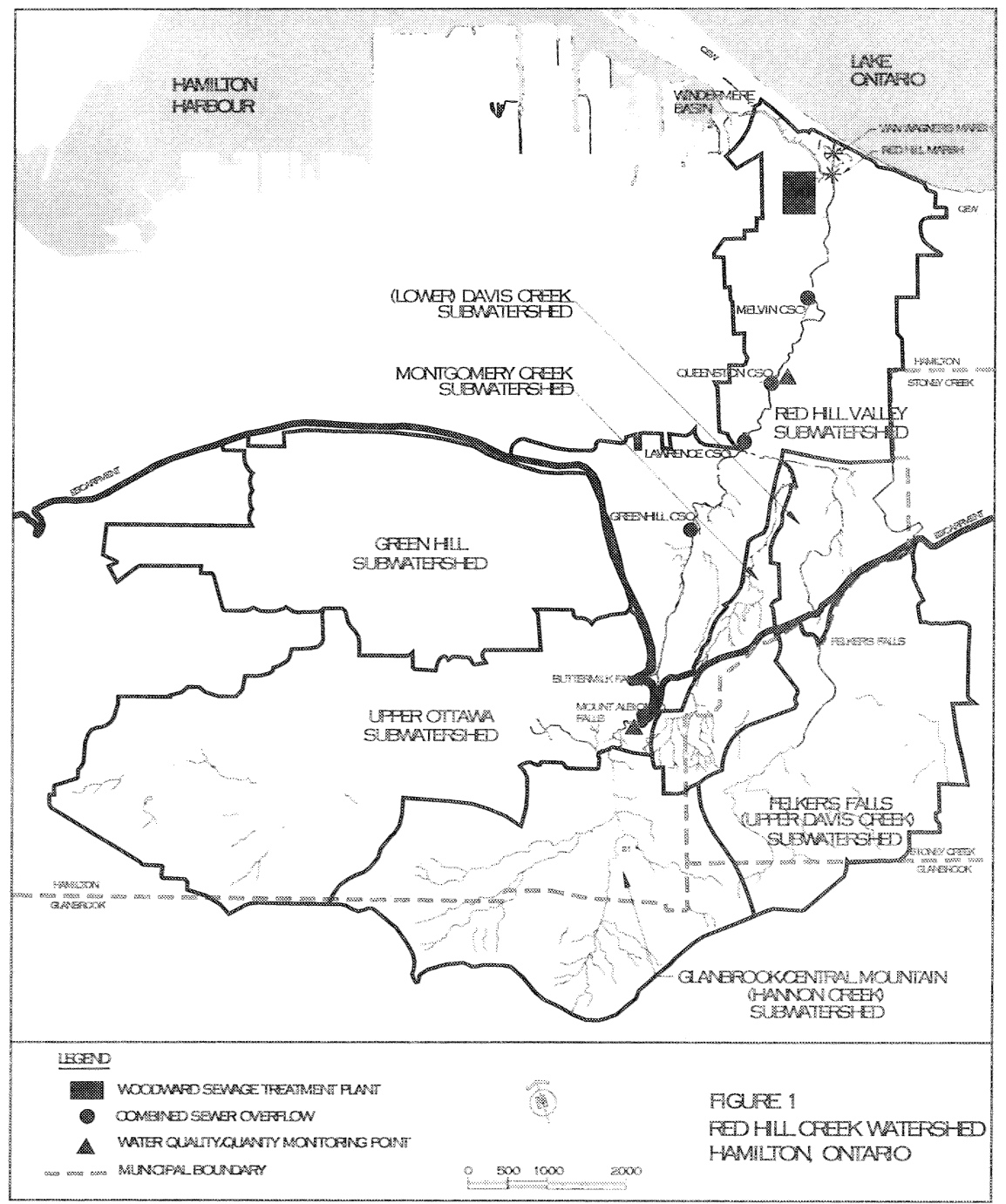

Figure 3.1 Redhill Creek watershed, Hamilton, Ontario.

The sediments in Red Hill Creek are not heavily contaminated (Wenghofer et al, 1997). Metal levels are generally at or below the low effect levels based on the Ontario Provincial Sediment Quality Guidelines (MOEE, 1992) and there are some minor elevations of PAH levels, particularly in the lower watershed. 
Benthic invertebrate surveys tend to parallel chemical data, indicating pollutant tolerant species in the upper and lower reaches of the Red Hill Creek, and more sensitive species in middle reaches.

\subsubsection{Background Documentation}

Considerable water quality data exist for the Red Hill Creek watershed. Water quality data have been gathered and analyzed through a variety of initiatives including:

- Ministry of Environment and Energy Water Quality Network (1964-1991), sampling at four locations

- Red Hill Valley Environment Rehabilitation Project - water quality and sediment sampling analysis

- Regional Municipality of Hamilton-Wentworth Pollution Control Plan - Combined sewer overflow abatement project

- Hamilton-Wentworth Natural Areas Inventory

- Water Quality sampling by area high school groups coordinated through McMaster University

- Research at McMaster University

- Hamilton Harbour - Remedial Action Plan (RAP) and associated initiatives.

\subsubsection{Mass Balance Modeling}

Given the volume of actual field data, it was necessary to develop a modeling tool to provide insight into the various sources of contaminants and to assist in the evaluation of various remedial options. To this end, a mass balance model for the Red Hill Creek watershed was prepared based on a spreadsheet analysis method.

The mass balance model provides annual loadings from both point (CSOs, water pollution control plant [WPCP]) and non-point (base flow, surface runoff) sources for selected water quality parameters. It was designed to account for the varying hydrologic response characteristics of pervious and impervious surfaces, as well as for differences in the quality of runoff from various land uses. The model is applicable to determining, at a planning level, the water quality changes to be expected from proposed development and land use changes within the watershed. One of the major strengths of the model is its ability to evaluate the effectiveness (in terms of reduced contaminant loading) of various best management practices (BMPs) which may be implemented to address changes in stormwater quantity and quality arising from development.

This chapter describes the modeling assumptions and approach, and provides an overview of results related to the Red Hill Creek watershed. 


\subsection{Water Quality Modeling: Base Model for Existing Land Use}

\subsubsection{Model Development}

The mass balance water quality model encompasses the Red Hill Creek watershed upstream of Queenston Road. The limits of the model, and the initial discretization, were selected to correspond with the two permanent stream flow gaging sites within the watershed (Albion Falls and Queenston Road, Figure 3.1). These gaging sites also coincide with two long-term water quality sampling sites. The watershed was divided into two catchments: the Upper Watershed (all drainage areas upstream of Albion Falls comprising the Upper Ottawa and Hannon Creek subwatersheds); and the Lower Watershed (all drainage areas located downstream of Albion Falls comprising Upper and Lower Davis Creek, Montgomery Creek and Red Hill Valley - to Queenston Road).

\subsubsection{Water Quantity Components}

\section{Rainfall and Runoff}

Annual rainfall, and runoff volume, were identified as the principal water quantity variables for analysis within the model. The annual rainfall input to the model of $852 \mathrm{~mm}$ was based on the average annual rainfall from 1985-1995 at the Royal Botanical Gardens (Environment Canada) gage in Hamilton. This annual depth of rainfall was assumed to be uniform over the entire watershed area.

The different hydrologic response characteristics of pervious and impervious surfaces were accounted for by assigning runoff coefficients to USDA Soil Conservation Service (SCS) soil types and impervious surfaces. Thus, total runoff from each subcatchment was calculated as the product of annual rainfall depth, land area and the runoff coefficient.

\section{Baseflow}

Non-point source discharges such as baseflow (dry weather flow) were included as a separate component of the mass balance model. Low flow rates at the MOEE gage sites were determined through analysis of stream flow data, hydrogeologic assessment and watershed modeling undertaken for the Watershed Plan (Terraqua, 1997; Philips Planning and Engineering, 1997).

\section{Combined Sewer Overflows}

Various reports have detailed the annual number and volume of combined sewer overflow (CSO) events within the Red Hill Creek watershed (Aquafor Beech 
Ltd., 1997; Paul Theil Associates Ltd., 1991). Annual volume estimates for the Greenhill, Queenston and Lawrence CSOs were included in the model. Since the Melvin CSO is outside the model limits, it was not included in the analysis.

\section{WPCP}

The Woodward Avenue Water Pollution Control Plant currently treats a volume of approximately 303 million litres per day (MLD), which is typically much greater than baseflow in the creek (approximately 20 MLD). The WPCP effluent is released at the outlet of the Red Hill Creek into Windermere Basin in Hamilton Harbour (Paul Theil and Associates Ltd, 1991).

\subsubsection{Water Quality Components}

The selection of pollutants for evaluation was based on evidence of exceedance of the PWQOs, as noted in previous studies of the watershed (Heagy, 1995). As well, parameters known to affect aquatic habitat and human recreation (total suspended solids) were included in the evaluation. The following contaminants were evaluated: ammonia $\left(\mathrm{NH}_{3}\right)$, biological oxygen demand (BOD), copper $(\mathrm{Cu})$, faecal coliform concentration (FCC), polycyclic aromatic hydrocarbons (PAH), total kjeldahl nitrogen (TKN), total phosphorus (TP), total suspended solids (TSS) and zinc (Zn). Annual mass pollutant loadings for runoff, baseflow and CSOs were calculated as the products of the event mean concentrations (EMCs) and annual flow volumes.

\section{Stormflow and Baseflow}

The storm runoff EMC and baseflow concentration values used in this water quality model (Table 3.1) were obtained from a variety of sources. The MOEE Water Quality Monitoring Network data (1980-1991) for the water quality monitoring stations at Barton Road and Albion Falls were analyzed to characterize the contaminant concentrations in the runoff. EMC values for each contaminant were calculated for the upper and lower subcatchments by averaging all concentrations recorded for the specific parameter of interest during stormflow conditions, based on the hydrologic and hydrogeologic assessment undertaken as part of the Watershed Plan (Terraqua, 1997; Philips Planning and Engineering, 1997). The EMC values calculated in this manner were consistent with values abstracted from the literature (Liscko and Struger, 1996; Wanielista and Yousef, 1993; Snodgrass, 1992). Further, the EMC values were adjusted for each land use based on the distribution in literature. Baseflow EMC values were calculated in a similar manner by averaging the in-stream concentrations for the MOEE data (1964-1991) during non-storm conditions. 
Table3.1 Event mean concentrations and baseflow concentrations for contaminants evaluated in the mass balance model.

\begin{tabular}{|c|c|c|c|c|c|c|c|c|c|c|}
\hline Parameter & Units & Baseflow & $\begin{array}{c}\text { Park/Open } \\
\text { Forest }\end{array}$ & Agricultural & Industrial & Institutional & Commercial & Residential & Highway & $\mathrm{CSO}$ \\
\hline $\mathrm{NH}_{3}$ & $\mathrm{mg} / \mathrm{L}$ & 0.5 & 0.1 & 1.2 & 0.3 & 0.3 & 0.3 & 0.3 & 0.2 & 1.6 \\
\hline BOD & $\mathrm{mg} / \mathrm{L}$ & 1.8 & 2 & 2 & 9 & 9 & 9 & 9 & 24 & 53 \\
\hline $\mathrm{Cu}$ & $\mathrm{mg} / \mathrm{L}$ & 0.003 & 0.005 & 0.005 & 0.034 & 0.034 & 0.034 & 0.034 & 0.136 & 0.025 \\
\hline FCC & $\begin{array}{l}\text { counts/ } \\
100 \mathrm{~mL}\end{array}$ & 3000 & 1000 & 5000 & 10000 & 10000 & 10000 & 25000 & 1000 & 200000 \\
\hline PAH & $\mathrm{ug} / \mathrm{L}$ & 0.6 & 0.05 & 0.1 & 1.5 & 1.5 & 1.5 & 1.0 & 2.3 & 1.8 \\
\hline TKN & $\mathrm{mg} / \mathrm{L}$ & 1 & 1 & 2.8 & 1.3 & 1.3 & 1.3 & 2 & 2.3 & 3.4 \\
\hline $\mathrm{TP}$ & $\mathrm{mg} / \mathrm{L}$ & 0.1 & 0.1 & 0.5 & 0.15 & 0.15 & 0.15 & 0.3 & 0.4 & 0.8 \\
\hline TSS & $\mathrm{mg} / \mathrm{L}$ & 10 & 100 & 400 & 150 & 150 & 150 & 150 & 150 & 200 \\
\hline $\mathrm{Zn}$ & $\mathrm{mg} / \mathrm{L}$ & 0.14 & 0.01 & 0.01 & 0.2 & 0.2 & 0.2 & 0.15 & 0.337 & 0.12 \\
\hline
\end{tabular}


Due to adjustments that were made to the averaged EMCs, and the lack of statistical data associated with the EMCs abstracted from literature, an uncertainty analysis of the data was not considered feasible. However, calibration of the EMCs to produce results representative of the long term instream conditions has resulted in a level of confidence consistent with the planning level estimate that this model is intended to provide.

\section{Combined Sewer Overflows}

Combined sewer overflow contributions were included in the analysis as point sources. Loadings were calculated by using the annual overflow volumes from Greenhill, Lawrence and Queenston CSOs (Aquafor Beech Ltd., 1997) and EMCs from previous studies (Wenghofer et al., 1997; Paul Theil Associates et $a l, 1991)$. The Pollution Control Plan (1991), which provides the ratio of sanitary sewage to stormflow in the CSOs ( $8 \%$ sanitary) and the parameter concentrations in each, was used to calculate the overall CSO EMCs for constituents analyzed in the model (Table 3.1). These values were found to be comparable with the outfall concentration values recorded in past studies (Wenghofer et al., 1997).

\section{WPCP}

Annual mass loadings of most pollutants from the Woodward Avenue WPCP to Hamilton Harbour were taken directly from reported values (Paul Theil Associates Ltd., 1991) and incorporated into the model. Table 3.2 provides a comparison of pollutant concentrations for sanitary sewage and treated effluent from the WPCP. The only exception to this method was PAH loading, which was calculated based on daily influent rate $(11.58 \mathrm{~kg} /$ day $)$ and a removal efficiency of $98.3 \%$ as determined by Steel and Melcer (1993). The calculated PAH loading to Red Hill Creek was $0.197 \mathrm{~kg} /$ day. It should be noted that all pollutant loading

Table 3.2 Contaminant concentrations in sanitary sewage and WPCP effluent.

\begin{tabular}{lccc}
\hline Parameter & Units & Sanitary Sewage $(\mathrm{mg} / \mathrm{L})$ & WPCP Effluent $(\mathrm{mg} / \mathrm{L})$ \\
\hline $\mathrm{NH}_{3}$ & $\mathrm{mg} / \mathrm{L}$ & 14 & 6 \\
$\mathrm{BOD}_{5}$ & $\mathrm{mg} / \mathrm{L}$ & 129 & 8 \\
$\mathrm{Cu}$ & $\mathrm{mg} / \mathrm{L}$ & 0.10 & 0.018 \\
$\mathrm{FCC}$ & $\# / 100 \mathrm{~mL}$ & $1 \times 10^{6}$ & 100 \\
$\mathrm{TKN}$ & $\mathrm{mg} / \mathrm{L}$ & 27.4 & 8.8 \\
$\mathrm{TP}$ & $\mathrm{mg} / \mathrm{L}$ & 6.0 & 0.4 \\
$\mathrm{TSS}$ & $\mathrm{mg} / \mathrm{L}$ & 302 & 20 \\
$\mathrm{Zn}$ & $\mathrm{mg} / \mathrm{L}$ & 2.6 & 0.009 \\
\hline
\end{tabular}

(ref. Paul Theil Associates and Beak Consultants, 1991) 
values used for the WPCP do not include bypass events; the total contaminant load from the WPCP would likely be larger than that computed in the mass balance model.

\subsubsection{Model Calibration}

The water quality model was calibrated through comparison with past hydrologic studies (Table 3.3) that developed calibrated and verified HSP-F models for the watershed. The calculated combination of baseflow and runoff was approximately $48 \%$ of the annual rainfall input, to match long term annual water budget calculation based on continuous simulation results (Philips Planning and Engineering, 1997) for the study area

The event mean concentrations for each parameter were also calibrated by adjusting the values for different land uses, within reasonable limits, until the calculated concentration was representative of the long-term instream concentrations at the MOEE monitoring stations.

Table 3.3 A comparison of mass balance model calibration to hydrologic model results.

\begin{tabular}{lcc}
\hline \multicolumn{1}{c}{ Parameter } & Hydrologic Model & Mass Balance Model \\
\hline $\begin{array}{l}\text { Average Annual Runoff (Streamflow) } \\
\text { as Percent of Rainfall (\%) }\end{array}$ & 45 & 48 \\
$\begin{array}{l}\text { Baseflow as a Percentage of Total } \\
\text { Streamflow (\%) }\end{array}$ & 20 & 18 \\
$\begin{array}{l}\text { Stormflow as Percentage of Total } \\
\text { Streamflow (\%) }\end{array}$ & 80 & 82 \\
\hline
\end{tabular}

\subsection{Model of the Future Watershed}

Contaminant loading for future land use was calculated in a similar manner to the existing conditions. The EMCs established in the base model were applied to the updated sub-catchment runoff, CSOs and baseflow to determine an annual load. Thus, changes reported in water quality are solely a result of changes in land use and imperviousnes within the watershed. Table 3.4 presents a comparison of the proposed future land uses against existing conditions.

Generally, changes to land use in the watershed would consist of converting the more pervious park/open space or agricultural land to the more impervious commercial, industrial or residential land use. Thus, future changes in land use would result in an increase in impervious area, which would correspondingly 
Table 3.4 Future land use parameters.

\begin{tabular}{|c|c|c|c|c|c|}
\hline General & \multicolumn{2}{|c|}{$\begin{array}{l}\text { Upper Sub-Catchment } \\
\text { (to Albion Falls) }\end{array}$} & \multicolumn{2}{|c|}{$\begin{array}{l}\text { Lower Sub-Catchment } \\
\text { (to Queenston Road) }\end{array}$} & $\begin{array}{c}\text { CSO } \\
\text { Sub- } \\
\text { Catchment }\end{array}$ \\
\hline Area (ha) & \multicolumn{2}{|c|}{2588.1} & \multicolumn{2}{|c|}{1925.0} & 1527 \\
\hline Area $(\%)$ & \multicolumn{2}{|c|}{$43 \%$} & \multicolumn{2}{|c|}{$32 \%$} & $25 \%$ \\
\hline Impervious Area (ha) & \multicolumn{2}{|c|}{973} & \multicolumn{2}{|c|}{572} & 561 \\
\hline Impervious Area (\%) & \multicolumn{2}{|c|}{$38 \%$} & \multicolumn{2}{|c|}{$30 \%$} & $37 \%$ \\
\hline LAND USE & (ha) & $\begin{array}{l}\% \text { change } \\
\text { from } \\
\text { existing }\end{array}$ & (ha) & $\begin{array}{l}\% \text { change } \\
\text { from } \\
\text { existing }\end{array}$ & N/A \\
\hline Park/Open/Vacant (ha) & 476.3 & $-26 \%$ & 558.1 & $-29 \%$ & \\
\hline Soil A & 0.0 & & 113.1 & & \\
\hline Soil BC & 292.2 & & 265.2 & & \\
\hline Soil C & 160.4 & & 152.3 & & \\
\hline Impervious & 23.8 & & 27.9 & & \\
\hline Agricultural (\%) & 404.1 & $-29 \%$ & 231.6 & $0 \%$ & \\
\hline Soil BC & 147.5 & & 166.4 & & \\
\hline Soil C & 236.3 & & 43.2 & & \\
\hline Impervious & 20.2 & & 11.0 & & \\
\hline Industrial (\%) & 452.1 & $+75 \%$ & 61.6 & $-37 \%^{1}$ & \\
\hline Soil BC & 70.0 & & 8.9 & & \\
\hline Soil C & 43.0 & & 6.5 & & \\
\hline Impervious & 339.1 & & 46.2 & & \\
\hline Institutional (\%) & 92.0 & $+11 \%$ & 3.8 & $0 \%$ & \\
\hline Soil BC & 46.7 & & 1.9 & & \\
\hline Soil C & 17.7 & & 0.8 & & \\
\hline Impervious & 27.5 & & 1.1 & & \\
\hline Commercial (\%) & 128.4 & $+13 \%$ & 46.2 & $+503 \%$ & \\
\hline Soil BC & 12.0 & & 10.7 & & \\
\hline Soil C & 20.0 & & 0.8 & & \\
\hline Impervious & 96.4 & & 34.6 & & \\
\hline Residential (\%) & 1023.1 & $+13 \%$ & 1000.5 & $+27 \%$ & \\
\hline Soil BC & 385.1 & & 352.9 & & \\
\hline Soil C & 178.2 & & 197.3 & & \\
\hline Impervious & 459.8 & & 450.3 & & \\
\hline $\begin{array}{l}\text { Highway } \\
100 \% \text { Impervious }\end{array}$ & 12.45 & $0 \%$ & 22.0 & $+1.0 \%$ & \\
\hline
\end{tabular}

increase runoff volume to Red Hill Creek. As well, the change to commercial, industrial and residential areas would increase the concentration of most pollutants in the runoff since EMCs are generally higher for these land uses. The overall result would be an increase in total pollutant loading over the present conditions. 


\subsection{Stormwater Quality Management}

To mitigate potential water quality impacts of proposed urban development, a number of stormwater management (SWM) facilities were considered (Figure 3.2). The location and size of potential SWM facilities were based on an assessment of opportunities for retrofitting existing facilities or constructing neighbourhood-scale facilities at existing major outfalls. Facilities which were previously proposed, as part of on-going land use plans, were also included in the analysis. To evaluate the potential combined effectiveness of all facilities, the base and future mass balance models were modified.

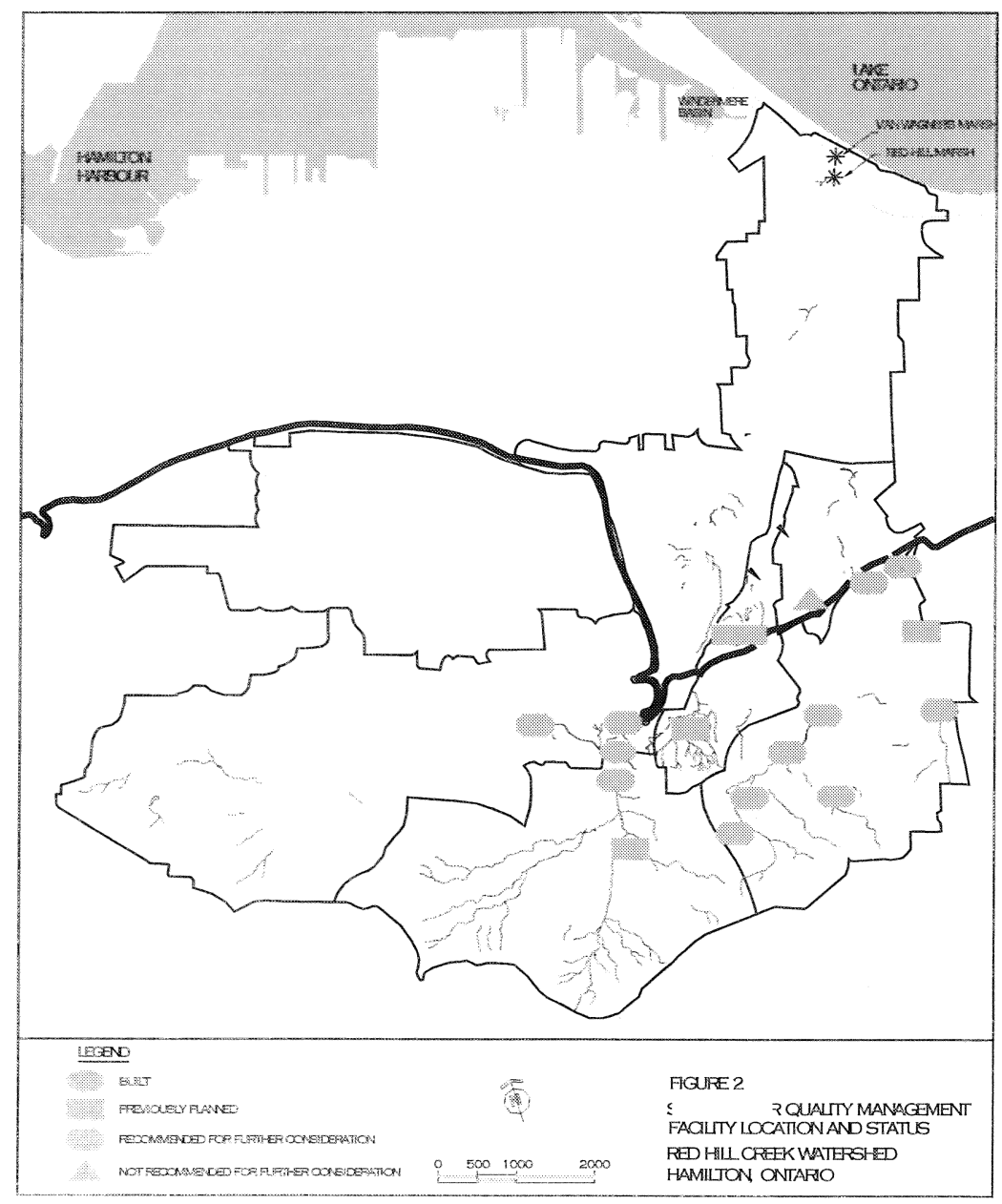

Figure 3.2 Stormwater quality management facility location and status. 
As most stormwater management facilities considered would be offline, annual flow volume and pollutant loading to each facility was determined on the basis of stormflow only (i.e. no baseflow contribution). The area draining to each facility was divided into land use categories and soil types in order to determine the hydrologic response characteristics and EMC. A separate continuous simulation analysis was undertaken using HSP-F to assess the relative fraction of the total runoff which would be treated within each off-line facility. Typically, the average volume of runoff treated would range between 20 and $100 \%$. Pollutant mass within the flow to each facility could then be calculated in the same manner as the base model.

\subsubsection{Off-line Stormwater Management Facility Performance}

A continuous simulation assessment using HSP-F (Donigian et al., 1993) of the expected long-term flow through the various facilities (within the treated flow rate range) was undertaken. This simulation was based on a ten year period (1978 - 1987) to determine the mean annual volume of flow that could be treated within off-line water quality facilities using an idealized catchment approach (Table 3.5 and Table 3.6).

Table 3.5 Summary of range of hydraulic treatment efficiency for idealized catchments within the Red Hill Creek watershed.

\begin{tabular}{|c|c|c|c|c|}
\hline \multirow{2}{*}{$\begin{array}{l}\text { Percent of } \\
\text { Directly } \\
\text { Connected } \\
\text { Impervious Area } \\
\text { (\%) }\end{array}$} & \multicolumn{4}{|c|}{ Range of Treatment Volume as a percent of Annual Runoff $(\%)$} \\
\hline & $\begin{array}{l}5 \mathrm{~m}^{3} / \mathrm{ha} \\
\text { Storage }\end{array}$ & $\begin{array}{l}10 \mathrm{~m}^{3} / \mathrm{ha} \\
\text { Storage }\end{array}$ & $\begin{array}{l}25 \mathrm{~m}^{3} / \mathrm{ha} \\
\text { Storage }\end{array}$ & $\begin{array}{l}50 \mathrm{~m}^{3} / \mathrm{ha} \\
\text { Storage }\end{array}$ \\
\hline 5 & $35-49$ & $42-56$ & $49-60$ & $57-60$ \\
\hline 15 & $31-41$ & $41-54$ & $52-64$ & $60-65$ \\
\hline 35 & $22-31$ & $33-44$ & $51-62$ & $62-71$ \\
\hline 55 & $16-22$ & $27-34$ & $46-56$ & $61-70$ \\
\hline
\end{tabular}

A range of directly-connected impervious coverage (i.e. $5 \%, 15 \%, 35 \%$, and $55 \%$ ) was modeled to represent various degrees of urban development, for the full simulation time period to provide a consistent basis for comparison. A range of storage $\left(5 \mathrm{~m}^{3} / \mathrm{ha}, 10 \mathrm{~m}^{3} / \mathrm{ha}, 25 \mathrm{~m}^{3} / \mathrm{ha} 50 \mathrm{~m}^{3} / \mathrm{ha}\right.$, volumes expressed in cubic metres of storage per hectare of contributing drainage area) facilities were modeled.

The HSP-F model was set up to allow base/low flows characteristic of the Red Hill Creek $(0.050 \mathrm{l} / \mathrm{s}$ ha) to bypass the water quality facilities. Storm flows in excess of base flow were diverted through the water quality facility for 
Table 3.6 Summary of average annual total and treated volumes for idealized catchments in the Red Hill Creek watershed.

\begin{tabular}{cccccc}
\hline $\begin{array}{c}\text { Percent } \\
\text { of } \\
\text { DCIA }\end{array}$ & $\begin{array}{c}\text { Average } \\
\text { Annual }\end{array}$ & \multicolumn{4}{c}{ Average Annual Treated Volume $\left(\mathrm{Mm}^{3}\right)$} \\
\cline { 3 - 6 }$(\%)$ & $\begin{array}{c}\text { Total Volume } \\
\left(\mathrm{Mm}^{3}\right)\end{array}$ & $\begin{array}{c}5 \mathrm{~m}^{3} / \mathrm{ha} \\
\text { Storage }\end{array}$ & $\begin{array}{c}10 \mathrm{~m}^{3} / \mathrm{ha} \\
\text { Storage }\end{array}$ & $\begin{array}{c}25 \mathrm{~m}^{3} / \mathrm{ha} \\
\text { Storage }\end{array}$ & $\begin{array}{c}50 \mathrm{~m}^{3} / \mathrm{ha} \\
\text { Storage }\end{array}$ \\
\hline 5 & 3.652 & 1.630 & 1.989 & 2.182 & 2.242 \\
& & $(44.6 \%)$ & $(54.5 \%)$ & $(59.7 \%)$ & $(61.4 \%)$ \\
15 & 4.102 & 1.613 & 2.123 & 2.564 & 2.688 \\
& & $(39.3 \%)$ & $(51.8 \%)$ & $(62.5 \%)$ & $(65.5 \%)$ \\
35 & 4.999 & 1.409 & 2.054 & 2.985 & 3.471 \\
& & $(28.2 \%)$ & $(41.1 \%)$ & $(59.7 \%)$ & $(69.4 \%)$ \\
55 & 5.897 & 1.176 & 1.887 & 3.139 & 4.030 \\
& & $(19.9 \%)$ & $(32.0 \%)$ & $(53.2 \%)$ & $(68.3 \%)$ \\
\hline
\end{tabular}

(\%) Percent Average Annual Treated Volume as a Percentage of Average Annual Total Volum

treatment. Major flows in excess of the capacities of the facilities were considered to bypass via an overflow spillway and were discounted from the treated flow volume. Each of the facilities was assumed to have a 24 hour drawdown period, hence outflow rates from each facility would vary according to the total storage provided.

Idealized curves depicting facility performance for each storage level for various impervious coverages (i.e. degree of urban land use) were developed (Figure 3.3). These curves represent the long term, percent of annual "treated" runoff volume versus storage level based on the full 10 year simulation period

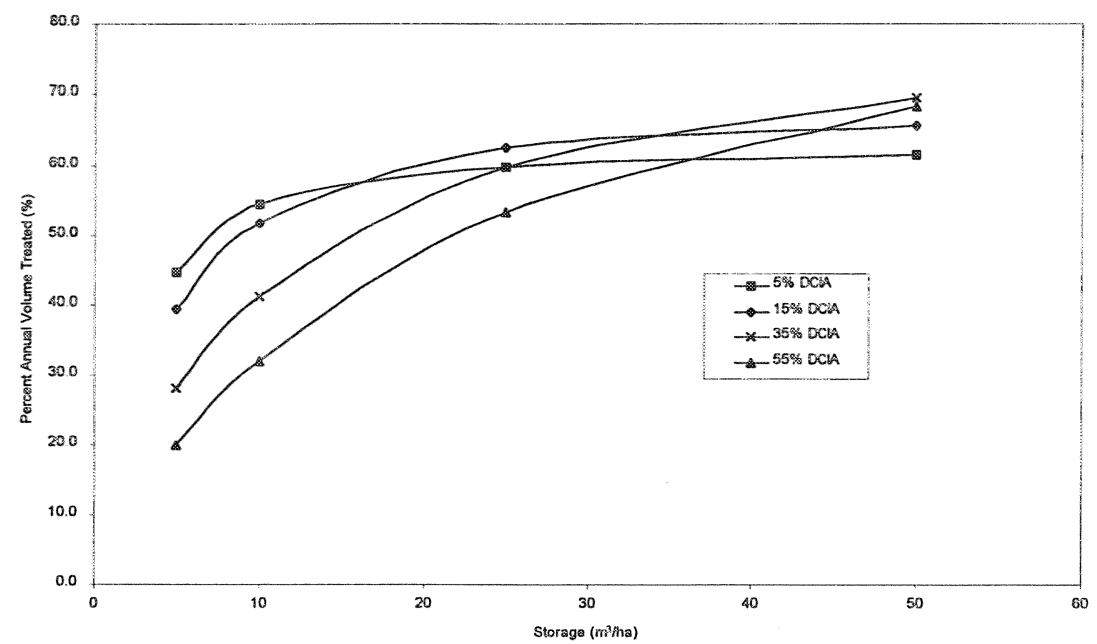

Figure 3.3 Relationship between stormwater storage volume and percent of annual volume treated for four levels of directly connected impervious area. 
The results of this analysis (i.e. determination of long-term fraction of annual runoff which is treated) were combined with the well-documented pollutant removal efficiencies of wetlands/wetponds, to determine an overall annual pollutant removal efficiency for each facility.

\subsubsection{Combined Sewer Overflow Management}

The Pollution Control Plan for Hamilton-Wentworth recommended that CSOs be reduced at the Melvin, Queenston and Lawrence outfalls (Paul Theil Ltd, 1991). A recent study, Class EA - Red Hill Creek CSO Control, (Aquafor Beech Ltd, 1997), recommended a management strategy consisting of a large diameter concrete pipe and sluice gates to store CSOs during an overflow event. After a storm event, the stored CSO would be routed to the sanitary interceptor and eventually treated at the Woodward Avenue WPCP. In terms of the mass balance model, the reduced values of annual CSO volume from the Queenston and Lawrence locations were incorporated to reflect CSO abatement. Table 3.7 provides a comparison of the annual CSO volume for existing and mitigated conditions based on the results of the 1997 study (Aquafor Beech).

Table 3.7 Existing and mitigated CSO annual volumes used in mass balance model.

\begin{tabular}{cccc} 
CSO Location & $\begin{array}{c}\text { Existing } \\
\text { Annual Volume } \\
\left(\mathrm{m}^{3}\right)\end{array}$ & $\begin{array}{c}\text { With Mitigation } \\
\text { Annual Volume } \\
\left(\mathrm{m}^{3}\right)\end{array}$ & $\begin{array}{r}\% \\
\text { Reduc }\end{array}$ \\
\hline Queenston & 13600 & 2900 & 79 \\
Lawrence & 28500 & 4100 & 86 \\
Greenhill & 360000 & N/A & N/A \\
Total & 440100 & 374200 & 15
\end{tabular}

(ref. Paul Theil Ltd. 1991; Aquafor Beech Ltd, 1997)

\subsection{Results of Comparative Mass Balance Modeling}

Table 3.8 provides a comparison of the contaminant loading from various sources for existing and future land use conditions. The reduction in pollutant loadings due to the abatement strategies modeled are also included in this table.

All parameters evaluated in the mass balance model were found to increase if the changes in land use to future conditions occurred without mitigation measures. Metals $(\mathrm{Cu}, \mathrm{Zn})$, PAHs and BOD were most significantly affected (19-27\% increase) by the land use change while ammonia $\left(\mathrm{NH}_{3}\right)$ and fecal coliforms were least affected ( $7-9 \%$ increase). 
Table 3.8 Mass balance model contaminant loading results for various land use conditions in the red hill creek watershed (in $\mathrm{kg} /$ year unless otherwise noted).

\begin{tabular}{|c|c|c|c|c|c|c|c|c|c|c|}
\hline Condition & Source & $\mathrm{NH}_{4}$ & $\mathrm{BOD}$ & $\mathrm{Cu}$ & $\mathrm{FCC}^{*}$ & $\mathrm{PAH}$ & TKN & $\mathrm{TP}$ & TSS & $\mathrm{Zn}$ \\
\hline \multirow[t]{5}{*}{$\begin{array}{l}\text { Existing } \\
\text { Land Use }\end{array}$} & Upper & 2591 & 59981 & 175 & $1.2 \times 10^{15}$ & 8 & 12894 & 1838 & 1220101 & 1093 \\
\hline & Lower & 1473 & 35987 & 90 & $8.7 \times 10^{14}$ & 4 & 8450 & 1219 & 728574 & 611 \\
\hline & Baseflow & 3627 & 19584 & 73 & $2.1 \times 10^{15}$ & 4 & 8704 & 870 & 72533 & 1015 \\
\hline & CSOs & 643 & 7238 & 16 & $8.0 \times 10^{14}$ & 1 & 1367 & 322 & 46242 & 48 \\
\hline & Total & 8333 & 122790 & 353 & $5.0 \times 10^{15}$ & 17 & 31415 & 4249 & 2067449 & 2768 \\
\hline \multirow[t]{6}{*}{$\begin{array}{l}\text { Future } \\
\text { Land Use }\end{array}$} & Upper & 2918 & 75422 & 228 & $1.4 \times 10^{15}$ & 10 & 14932 & 2080 & 1407616 & 1428 \\
\hline & Lower & 1731 & 47534 & 132 & $1.1 \times 10^{15}$ & 5 & 10318 & 1518 & 857858 & 798 \\
\hline & CSOs & 643 & 7238 & 16 & $8.0 \times 10^{14}$ & 1 & 1367 & 322 & 46242 & 48 \\
\hline & Baseflow & 3627 & 19584 & 73 & $2.1 \times 10^{15}$ & 4 & 8704 & 870 & 72533 & 1015 \\
\hline & Total & 8919 & 149777 & 448 & $5.4 \times 10^{15}$ & 21 & 35321 & 4790 & 2384248 & 3286 \\
\hline & $\begin{array}{l}\% \Delta \text { from } \\
\text { existing }\end{array}$ & 7 & 22 & 27 & 9 & 22 & 12 & 13 & 15 & 19 \\
\hline \multirow{7}{*}{$\begin{array}{l}\text { Future } \\
\text { Land Use } \\
\text { with } \\
\text { SWM } \\
\text { Facilities } \\
\text { and } \\
\text { CSO } \\
\text { Abate- } \\
\text { ment }\end{array}$} & Upper & 2163 & 57112 & 152 & $7.2 \times 10^{14}$ & 6 & 13176 & 1540 & 800379 & 1051 \\
\hline & Lower & 1542 & 43609 & 115 & $9.1 \times 10^{14}$ & 5 & 9908 & 1381 & 709605 & 721 \\
\hline & $\mathrm{CSO}$ & 587 & 6606 & 15 & $7.3 \times 10^{14}$ & 1 & 1248 & 294 & 42205 & 44 \\
\hline & Baseflow & 3627 & 19584 & 73 & $2.1 \times 10^{15}$ & 4 & 8704 & 870 & 72533 & 1015 \\
\hline & Total & 7918 & 126911 & 353 & $4.5 \times 10^{15}$ & 16 & 33035 & 4085 & 1624722 & 2831 \\
\hline & $\begin{array}{l}\% \Delta \text { from } \\
\text { existing }\end{array}$ & -5 & 3 & 0 & -10 & -6 & 5 & -4 & -21 & 2 \\
\hline & $\begin{array}{l}\% \Delta \text { from } \\
\text { future }\end{array}$ & -11 & -15 & -21 & -18 & -23 & -7 & -15 & -32 & -14 \\
\hline
\end{tabular}

Units = counts/year

Upper source: Drainage area upstream of Albion Falls

Lower source: Drainage area between Barton Street and Albion Falls

NOTE: $\quad$ Loading data does not include Woodward Ave WPCP

The mass balance model, which facilitated the evaluation of a series of endof-pipe management strategies, demonstrated a decrease in contaminant loading for all parameters evaluated. The maximum effect of mitigation was observed for total suspended solids loading which would decrease by $32 \%$ from existing conditions. 


\subsection{Conclusions}

Watershed planning within the Red Hill Creek watershed established a need to develop methods which both define the current state of the watershed and provide a measure of the watershed's future condition. To this end, the mass balance water quality model designed for the Red Hill Creek was effective in producing planning level estimates of pollutant loading. Based on both water quality and quantity parameters, the model was successful in characterizing pollutant loading from various sources and determining water quality changes due to proposed development within the watershed. As well, the model was useful in evaluating the impact and effectiveness of potential best management practices selected to mitigate the effects of development on water quality. While a quantitative level of confidence was difficult to determine based on the sources of data used in the analysis, model calibration and the relative nature of the results have provided a certain qualitative level of confidence. Future studies could include a sensitivity analysis of the input data used in the modeling process.

In general, design of a successful water quality mass balance model requires certain key aspects to be addressed. Firstly, EMC data are necessary to characterize pollutant concentrations in runoff from various land use conditions. Since such information tends to be site specific, further research on EMC values would be advantageous. As well, long-term streamflow gauging is useful in determining differences in high and low flow volumes. This information is necessary to calculate baseflow volumes and is valuable in verifying annual runoff volumes. Streamflow data combined with water quality sampling data provide information on average instream pollutant concentrations during low flow conditions. Continuous simulation analysis (HSP-F) is also valuable to the model design since runoff coefficients determined through HSP-F can be used to calibrate the mass balance model water quantity calculations. In addition, continuous simulation is useful in determining the effectiveness of various mitigation techniques such as wet ponds and wetlands.

\section{Acknowledgments}

We greatly appreciate the assistance and support offered by the special projects office of the Regional Municipality of Hamilton-Wentworth. In addition, technical input provided by the various members of the consultant team responsible for the watershed plan has been most useful to this undertaking. Finally, we would like to thank all of the many committed stakeholders who provided their time and input at several key points during the process. 


\section{References and Bibliography}

Aquafor Beech Ltd., 1997. Class EA: Red Hill Creek CSO control, ESR Draft Report. Prepared for the Regional Municipality of Hamilton-Wentworth.

Beak Consultants Limited and Aquafor Engineering Limited, 1991. Credit Valley Water Management Strategy - Phase II, Supporting Document No. 2: Water Quantity' Quality Modelling and Impact Assessment. Prepared for Credit Valley Conservation Authority, Meadowvale, Ontario.

Conestoga-Rovers and Associates Ltd. and Ecologists Ltd., 1996. Biological Resource Documentation Report - Ottawa Street Landfill Rehabilitation Project.

Donigian, A.S., B.R. Bicknell, J.C. Imhoff, J.L. Kittle, R.C. Johanson, 1993. Hydrological Simulation Program - Fortran, Release 10. U.S. Environmental Protection Agency, Athens, Georgia.

Gartner Lee and Taro Aggregates Ltd., January 1995. Taro East Quarry Environmental Assessment: Surface Water Impact Assessment.

Heagy, A.E., 1995. Hamilion-Wentworth Natural Areas Inventory, Volume I, Hamilton Naturalists' Club. Prepared for the Hamilton Region Conservation Authority.

Irvine, K., I. Droppo, T.P. Murphy and M. Stirrup. 1997. "Annual Loading Estimates of Selected Metals and PAHs in CSOs, using a Continuous PCSWMM Approach." Journal of Water Management Modeling R200-20. doi: 10.14796/JWMM.R200-20.

James, William (Ed.), 1987. Pollution Control Planning. Proceedings of the Ontario Ministry of the Environment Technology Transfer Workshop on Pollution Control Planning held in Toronto, Ontario, February 9-10, 1987.

Kummler, R., C.C. Lin and Y. Rhee. 1996. "Estimated CSO Conventional and Toxic Concentrations from Analysis of Wastewater Treatment Plant Influent Data." Journal of Water Management Modeling R191-16. doi: 10.14796/JWMM.R191-16.

Licsko, Z. and J. Struger. 1996. "Trace Metals Contamination of Urban Streams and Stormwater Detention Ponds." Journal of Water Management Modeling R191-17. doi: 10.14796/JWMM.R191-17.

Maltby, L., D.M. Forrow, A.B.A. Boxall, P. Callow and C.I. Betton. 1995a. The Effects of Motorway Runoff on Freshwater Ecosystems. 1. Field Study. Environmental Toxicology and Chemistry, Vol 14. 1979-1092.

Maltby, L., D.M. Forrow, A.B.A. Boxall, P. Callow and C.I. Betton. 1995b. The Effects of Motorway Runoff on Freshwater Ecosystems. 2. Identifying Major Toxicants. Environmental Toxicology and Chemistry. 14. 1093-1101.

Marsalek, J., B. Brownlee, T. Mayer, S. Lawal and G. Larkin, 1997. Heavy Metals and PAHs in

Highway Bridge Runoff. Prepared for the National Water Research Institute.

McCarry, B., February 1996. Red Hill Creek as a Source of Genotoxins to Hamilton Harbour. McMaster University.

Metropolitan Toronto and Region Remedial Action Plan (Metro Region RAP), 1995. Metropolitan Toronto Waterfront Wet Weather Outfall Study - Phase II City of Toronto. ISBN 0-7778-4787-6. Toronto, Ontario. 
MOEE and Metro Toronto \& Region Conservation Authority, 1996. Performance Assessment of an Off Line Stormwater Management Pond: Heritage Estates Stormwater Management Pond, Richmond Hill, Ontario.

Ministry of Environment and Energy, 1995. Water Quality Monitoring Network, data for Red Hill Creek in digital format, 1964 to 1991.

Paul Theil Associates Ltd. and Beak Consultants Ltd., 1991. Regional Municipality of Hamilton- Wentworth Pollution Control Plan.

Philips Planning and Engineering Ltd., August 1997. Montgomery Creek Class Environmental Assessment.

Philips Planning and Engineering Ltd., November 1997. Red Hill Creek Watershed Plan: Surface Water Report. Prepared for the Regional Municipality of Hamilton-Wentworth.

Schroeter, H.O., 1997. Toxic Contaminant Loading from Municipal Sources in Ontario Areas of Concern. Water Quality Resource Journal. Vol. 23, No. 1. pp 7-22.

Schueler, T.R, 1987. Controlling Urban Runoff: A Practical Manual for Planning and Designing Urban BMPs. Prepared for Metropolitan Water Resources Planning Board.

Sleeman, J., 1995-96. Benthic Macroinvertibrate Monitoring of Hamilton Area Streams by High School Students. McMaster University.

Smith, D.L. and B.N. Lord, 1990. Highway Water Quality Control - Summary of 15 Years of Research, Transportation Research Record No. 1279.

Snodgrass, W.J. and J.C. P'ng, 1992. Implementation of Pollution Control Measures for Urban Stormwater Runoff. University of Toronto University Press, Downsview, Ontario.

Snodgrass, W.J., 1981. Hamilton Harbour Study-Material Inputs to Hamilton Harbour. McMaster University.

Steel, Paula and Henryk, Melcer, 1993. An Assessment of the Presence of Polycyclic Aromatic Hydrocarbons (PAHs) in the Hamilton Woodard Sewage Treatment Plant. Prepared for the Wastewater Technology Centre, Burlington, Ontario.

Sutherland, R. and S.L. Jelen. 1996. "Sophisticated Stormwater Quality Modeling is Worth the Effort." Journal of Water Management Modeling R191-01. doi: 10.14796/JWMM.R191-01.

Terraqua Investigations Ltd., 1997. Red Hill Creek Watershed Plan: Hydrogeological Inventory. Prepared for the Regional Municipality of Hamilton-Wentworth.

Torno, H., J. Marsalek, M. Desbordes, 1986. Urban Runoff Pollution. Springer- Verlag: New York, NY. pp 8-11.

U.S.EPA, 1983. Final Report of the Nationwide Urban RunoffProgram. Water Planning Division, US. Environmental Protection Agency, Washington, D.C.

Wanielista, M.P. and Y.A. Yousef, 1993. Stormwater Management. John Wiley and Sons Inc, New York, NY.

Wenghofer, C., B. Duncan and J. Struger, 1997. Red Hill Creek, Hamilton, Ontario: Water and Sediment Quality, and Effects on Fish and Fish Habitat.

Whipple, W., 1983. Stormwater Management in Urbanizing Areas. Prentice Hall: New York. pp 69.

Woodward-Clyde Consultants, 1990. Urban Targeting and BMP Selection: An Information and Guidance Manual for State Nonpoint Source Program Staff Engineers and Mangers. Prepared for US EPA, Region V, Water Division, Chicago IL and Offices of Water Regulations and Standards, Washington, DC. 